\title{
Spectrophotometric Determination of the pKa, Isosbestic Point and Equation of Absorbance vs. pH for a Universal pH Indicator
}

\author{
L. E. Vidal Salgado, C. Vargas-Hernández \\ Laboratory of Optical Properties of Materials (POM), National University of Colombia, Manizales, Colombia \\ Email: cvargash@unal.edu.co
}

Received 3 October 2014; revised 20 November 2014; accepted 7 December 2014

Copyright (C) 2014 by authors and Scientific Research Publishing Inc.

This work is licensed under the Creative Commons Attribution International License (CC BY). http://creativecommons.org/licenses/by/4.0/

(c) ()) Open Access

\begin{abstract}
The pKa and the isosbestic point of the universal pH indicator Carlo Ebra 1-11 (catalog number 45712) were determined using UV-Vis spectrophotometry. Aqueous buffer solutions with pHs ranging from 3.83 to 10.85 were mixed. Four methods-two graphical and two mathematicalwere used to estimate the acid dissociation constant (pKa) and isosbestic point using absorbance measurements. The equation for the dependence of the absorbance on $\mathrm{pH}$ at $\lambda=600 \mathrm{~nm}$ was obtained using calibration curves. The resulting average pKa of the four methods was 8.277 with a standard deviation of 0.1728 . The results obtained using the mathematical methods were very similar, with a deviation of 0.0014 ; the average pKa determined using these methods was $8.263 \pm$ 0.001. The literature contains no previous reports of the pKa of this indicator. The isosbestic point occurs at a wavelength of $494 \mathrm{~nm}$, with an absorbance of 0.46 .
\end{abstract}

\section{Keywords}

Design of Buffers, Spectrophotometric Titration, Determination of pKa, Isosbestic Point, Universal pH Indicator

\section{Introduction}

The value of the acid dissociation constant (pKa) is an important parameter that indicates the degree of ionization of molecules in solution at different $\mathrm{pH}$ values. Many chemical, physical and biological properties of natural and synthetic compounds are governed by the interactions of acidic and basic groups. In such compounds, 
the pKa controls many aspects of metabolism and even transport across membranes; therefore, its study is of significant interest in biology, pharmaceutics, medicine, and numerous other scientific fields. Zscherp et al. [1] determinedthe transient pKa changes of a single amino acid side chain in bacteriorhodopsin, a protein important in photosynthesis. Baran et al. [2] investigated the pKa of amino acid complexes and their relationship to atomic orbitals. Several groups [3]-[6] have investigated the behaviors of different drugs, including those used against cancer, and the dependence of their behaviors on their pKa values. Novel pKa determination methods that use $\mathrm{pH}$ colorimetric indicators have also been reported [7]-[9].

Two main methods exist for determining the pKa of a compound: potentiometric titration and spectrophotometric titration. The main advantage of the second method is the ability to obtain a titration curve, which allows for estimation at any point without necessitating an experiment. In contrast, potentiometric titration requires knowledge of the equilibrium concentrations of the reagents, which are not necessary in spectrophotometric titration because the ratio of the concentrations of the basic and acidic parts is obtained from the results of absorbance measurements. When the mixing of a solution and an indicator is investigated spectrophotometrically, the mixture absorbs in the UV region (250 - $380 \mathrm{~nm}$ ), whereas the indicator, depending on the $\mathrm{pH}$ of the solution, absorbs in the visible region ( $380-700 \mathrm{~nm}$ ). The pKa can be determined from the spectrophotometric data using different methods. Meloun et al. [10] [11] describe multiwavelength analysis and nonlinear least squares regression methods. Computational methods, such as SQUAD (84) 16 and SPECFIT/32, and some new methods [12]-[15] have also been developed.

\section{Theoretical Foundations}

When an acid HA is dissolved in water, equilibrium is established:

$$
\mathrm{HA}+\mathrm{H}_{2} \mathrm{O} \rightleftarrows \mathrm{A}^{-}+\mathrm{H}_{3} \mathrm{O}^{+}
$$

The acid HA transfers a proton to water, and it becomes the anion $\mathrm{A}^{-}$. This anion tends to retrieve the proton and behave as a base; $\mathrm{A}^{-}$is therefore referred to as the "conjugate base" of acid HA, and HA and $\mathrm{A}^{-}$are referred to as a "conjugate pair" [16] [17]. A shift of the equilibrium in Equation (1) to the right or left depends on the relative strengths of the $\mathrm{HA}$ and $\mathrm{H}_{3} \mathrm{O}^{+}$acids. The "strength" of an acid refers its tendency to transfer protons, and one method of standardizing its force is to compare the protonation state when it interacts with water. The result of this comparison is expressed as the "acid dissociation constant," Ka, as follows:

$$
\mathrm{Ka}=\frac{\left[\mathrm{A}^{-}\right]\left[\mathrm{H}_{3} \mathrm{O}^{+}\right]}{[\mathrm{HA}]}
$$

$\mathrm{Ka}$ is a constant of the stoichiometric equilibrium defined in terms of the concentration ratio $\left[\mathrm{A}^{-}\right] /[\mathrm{HA}]$, which can be determined spectrophotometrically [18]. If a solution with a total concentration of indicator $\mathrm{C}_{\mathrm{T}}$ becomes very acidic, all indicator exists as HA. The absorbance of the solution at a given wavelength $\lambda$ is given by

$$
\mathrm{A}_{\mathrm{HA}}=\varepsilon_{\mathrm{HA}} \cdot \mathrm{b} \cdot \mathrm{C}_{\mathrm{T}}
$$

where $\varepsilon_{\mathrm{HA}}$ is the molar absorptivity of HA at wavelength $\lambda$ and $\mathrm{b}$ is the width of the cell containing the solution. If the solution is too basic, the same concentration of indicator is converted entirely into $\mathrm{A}^{-}$and the absorbance at the same wavelength is given by

$$
\mathrm{A}_{\mathrm{A}^{-}}=\varepsilon_{\mathrm{A}^{-}} \cdot \mathrm{b} \cdot \mathrm{C}_{\mathrm{T}}
$$

where $\varepsilon_{\mathrm{A}^{-}}$is the molar absorptivity of $\mathrm{A}^{-}$. At an intermediate $\mathrm{pH}$, the absorbance is given by

$$
\mathrm{A}_{\mathrm{HA}}=\varepsilon_{\mathrm{HA}} \cdot \mathrm{b} \cdot \mathrm{C}_{\mathrm{HA}}+\varepsilon_{\mathrm{A}^{-}} \cdot \mathrm{b} \cdot \mathrm{C}_{\mathrm{A}^{-}}
$$

where the total concentration is defined in any condition as

$$
\mathrm{C}_{\mathrm{T}}=\mathrm{C}_{\mathrm{HA}}+\mathrm{C}_{\mathrm{A}^{-}}
$$

For a given $\mathrm{C}_{\mathrm{T}}$, Equations (3)-(6) can be combined to obtain

$$
\frac{\left[\mathrm{A}^{-}\right]}{[\mathrm{HA}]}=\frac{\mathrm{C}_{\mathrm{A}^{-}}}{\mathrm{C}_{\mathrm{HA}}}=\frac{\mathrm{A}-\mathrm{A}_{\mathrm{HA}}}{\mathrm{A}_{\mathrm{A}^{-}}-\mathrm{A}}
$$


This relationship must be evaluated at multiple wavelengths, including one where HA absorbs appreciably but $\mathrm{A}^{-}$does not, one where $\mathrm{A}^{-}$is much more absorbent than HA, and another where the absorbance of the two species is approximately the same. The $\mathrm{pH}\left(-\log \left[\mathrm{H}_{3} \mathrm{O}^{+}\right]\right)$of the solutions must be in the transition range of the indicator so that both HA and A-are present in appreciable concentrations. Ka can be evaluated graphically by converting Equation (2) to logarithmic form:

$$
\log \mathrm{Ka}=\log \left[\mathrm{H}_{3} \mathrm{O}^{+}\right]+\log \frac{\left[\mathrm{A}^{-}\right]}{[\mathrm{HA}]}
$$

In addition, the combination of Equation (7) and the definition of $\mathrm{pKa}=-\log \mathrm{Ka}$ results in

$$
\log \left(\frac{A-A_{H A}}{A_{A^{-}}-A}\right)=p H-p K a
$$

Therefore, a graph of $\log \left[\left(\mathrm{A}-\mathrm{A}_{\mathrm{HA}}\right) /\left(\mathrm{A}_{\mathrm{A}}-\mathrm{A}\right)\right]$ vs. $\mathrm{pH}$ has an ideal slope of one. If this condition holds, the $y$-axis intercept gives the negative pKa directly. However, the experimental slope is not usually exactly 1 , necessitating that the $\mathrm{pH}$ values of the measurements be extrapolated to $\mathrm{pH}=0$ (which is typically a factor of $10^{6}$ in concentration), resulting in a very large error for the pKa value. In contrast, if the least-squares equation is solved for the intercept with the $x$-axis, where $\log \left[\left(A-A_{H A}\right) /\left(A_{A}-A\right)\right]=0$, the pKa results are obtained with very little uncertainty. At this intercept, $\left[\mathrm{A}^{-}\right] /[\mathrm{HA}]=1$, indicating that the concentrations of the acid and its conjugate base are equal. When $\mathrm{HA}$ is a strong acid, a value for Ka in aqueous solutions cannot be defined, because HA molecules cannot be detected; the value of Ka is therefore very high or infinite. In contrast, a very low value indicates that the dissociation Ka involves a very small fraction of the total acid present. The isosbestic point is the point on the graph of absorbance vs. $\mathrm{pH}$ where the molar absorption coefficients of the species in equilibrium are the same.

\section{Experimental Methods}

Preparation of solutions. Three families of buffers covering the $\mathrm{pH}$ range between 2.3 and 10.85 were prepared using four solutions of citrate buffer at $\mathrm{pH}$ 2.3, 3.05, 4.37 and 5.4 containing citric acid and its conjugate base. Table 1 shows the reactants and the proportions used to prepare the citrate buffer.

The calculation model is based on the Henderson-Hasselbach Equation (10) and on the final concentration Cf of the acid and its conjugate base (Equation (4)):

$$
\begin{aligned}
& \mathrm{pH}=\mathrm{pKa}-\log \left([\mathrm{HA}] /\left[\mathrm{A}^{-}\right]\right) \\
& \mathrm{Cf}=[\mathrm{HA}]-\left[\mathrm{A}^{-}\right]
\end{aligned}
$$

To calculate the mass of the reagents, Equations (10) and (11) are solved simultaneously by setting the desired $\mathrm{pH}$ and concentration (Cf). These equations were solved using a program developed in LabVIEW for greater agility. The results for the formulations are shown in Table 2.

The calculated $\mathrm{pH}$ values exhibited some differences, especially at higher $\mathrm{pH}$ levels, as illustrated in Figure 1. The standard deviation of the data was $0.728 \mathrm{pH}$ units.

A second phosphate buffer was prepared using two stock solutions: $100 \mathrm{ml}$ of $0.2 \mathrm{M}$ monosodium phosphate and disodium phosphate (Table 3), which were mixed to obtain buffer solutions with pH 6.5, 7.08 and 7.7.

The preparation of stock solutions required $2.84 \mathrm{~g}$ of monosodium phosphate (monohydrate) and $2.76 \mathrm{~g}$ of disodium phosphate, which were then diluted with distilled-and-deionized water to a volume of $100 \mathrm{ml}$. Finally, these stock solutions were combined in the proportions listed in Table 4.

Table 1. Reagents used in the preparation of the citrate buffer.

\begin{tabular}{cccc}
\hline Name & Formula & Molecular weight (g/mol) & pKa \\
\hline Citric acid [weak acid] & $\mathrm{C}_{6} \mathrm{H}_{8} \mathrm{O}_{7}$ & 192.12 & 3.13 \\
Sodiumcitrate [conjugate-base salt] & $\mathrm{Na}_{3} \mathrm{C}_{6} \mathrm{H}_{5} \mathrm{O}_{7}$ & 258.06 & \\
\hline
\end{tabular}


Table 2. Preparation of the citrate buffer at different $\mathrm{pH}$ levels and concentrations.

\begin{tabular}{ccccccc}
\hline & \multicolumn{2}{c}{ Volume of the STOCK aliquot $(\mathbf{m l})$} & \multicolumn{3}{c}{ Final preparation } \\
\hline Calculated $\mathbf{p H}$ & Solution $\mathbf{C}_{\mathbf{6}} \mathbf{H}_{\mathbf{8}} \mathbf{O}_{7}$ & Solution $\mathbf{N a}_{\mathbf{3}} \mathbf{C}_{\mathbf{6}} \mathbf{H}_{\mathbf{5}} \mathbf{O}_{\mathbf{7}}$ & $\begin{array}{c}\text { Final volume buffer } \\
(\mathbf{m l})\end{array}$ & $\begin{array}{c}\text { Concentration buffer } \\
(\mathbf{M})\end{array}$ & Obtained pH \\
\hline 3.83 & 5 & 25 & 50 & 0.12 & 5.40 \\
3.35 & 15 & 25 & 50 & 0.16 & 0.12 & 3.37 \\
3.13 & 15 & 15 & 50 & 0.18 & 3.05 \\
2.83 & 30 & 15 & 50 & 0.12 & 2.30 \\
\hline
\end{tabular}

Table 3. Reagents used to prepare the phosphate buffers.

\begin{tabular}{cccc}
\hline Name & Formula & Molecular weight (g/mol) & pKa \\
\hline Monosodium phosphate (monohydrate) & $\mathrm{NaH}_{2} \mathrm{PO}_{4} \cdot \mathrm{H}_{2} \mathrm{O}$ & 137.98 & 7.21 \\
Monosodium phosphate & $\mathrm{NaH}_{2} \mathrm{PO}_{4}$ & 119.98 & \\
Disodium phosphate & $\mathrm{Na}_{2} \mathrm{HPO}_{4}$ & 141.96 & \\
\hline
\end{tabular}

Table 4. Preparation of phosphate buffer at different concentrations and $\mathrm{pH}$.

\begin{tabular}{|c|c|c|c|c|c|}
\hline \multirow[b]{2}{*}{ Calculated pH } & \multicolumn{2}{|c|}{ Volume of the STOCK aliquot (ml) } & \multicolumn{3}{|c|}{ Final preparation } \\
\hline & $\begin{array}{c}\mathrm{NaH}_{2} \mathrm{PO}_{4} \\
\text { solution }\end{array}$ & $\begin{array}{c}\mathrm{Na}_{2} \mathrm{HPO}_{4} \\
\text { solution }\end{array}$ & $\begin{array}{c}\text { Final volume buffer } \\
(\mathrm{ml})\end{array}$ & $\begin{array}{l}\text { Concentration buffer } \\
\text { (M) }\end{array}$ & $\begin{array}{c}\text { Obtained } \\
\text { pH }\end{array}$ \\
\hline 7.51 & 5 & 10 & 25 & 0.12 & 7.08 \\
\hline 7.30 & 18 & 22 & 50 & 0.16 & 6.81 \\
\hline 7.21 & 10 & 10 & 50 & 0.08 & 6.80 \\
\hline 7.10 & 22 & 17 & 100 & 0.078 & 6.67 \\
\hline 6.91 & 20 & 10 & 100 & 0.06 & 6.50 \\
\hline
\end{tabular}

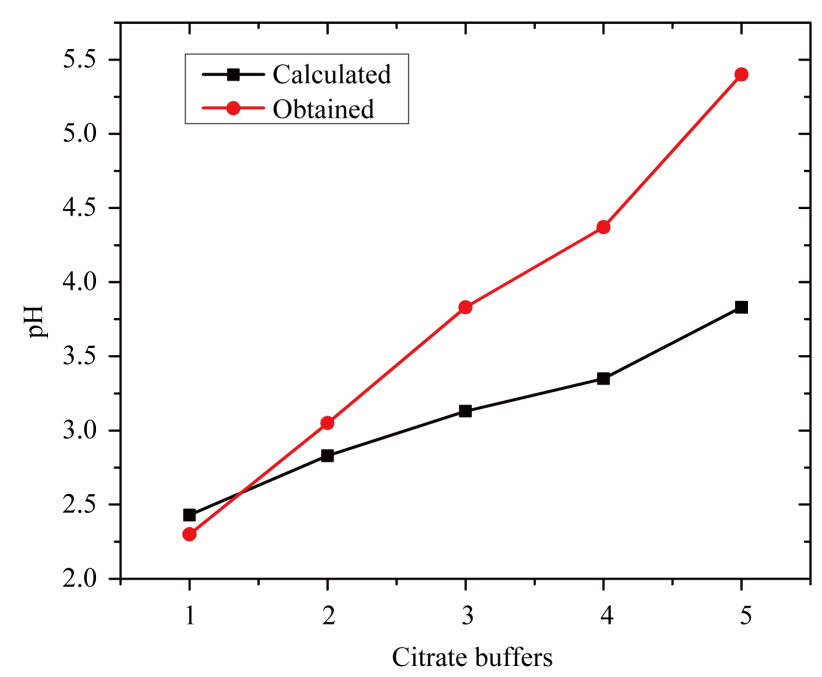

Figure 1. Comparison between the calculated and obtained $\mathrm{pH}$ values for citrate buffers. 
Figure 2 shows the curves of the calculated and obtained $\mathrm{pH}$ values for the prepared phosphate buffers. The obtained $\mathrm{pH}$ values were higher than expected, with a standard deviation of $0.434 \mathrm{pH}$ units.

The third set of solutions consisted of ammonium buffers composed of a mixture of two stock solutions: ammonia and ammonium chloride. The calculations were similar to those used for the preparation of the phosphate buffers. Table 5 shows the details of the preparation.

Figure 3 shows the curves for the calculated and experimental $\mathrm{pH}$ values for the ammonium buffer solutions. The obtained values were higher than expected, with a standard deviation of $0.624 \mathrm{pH}$ units.

Even though the buffers did not have $\mathrm{pH}$ values equal to the calculated values, they were very stable and retained their constant $\mathrm{pH}$ value for months. The most important factor for the spectrophotometric determination of $\mathrm{pKa}$ is that the $\mathrm{pH}$ be known and stable.

\section{Results and Discussion}

Spectrophotometric measurements. Absorbance measurements were performed using a Thermo Scientific Evolution $300 \mathrm{UV}$-Vis spectrophotometer in the wavelength range between 380 and $700 \mathrm{~nm}$ (visible spectrum). In this study, universal indicator pH 1 - 11 (catalog number 45712, Carlo Ebra, Milano, Italy) was used. The pH measurements were performed using an Oakton $\mathrm{pH} 2700 \mathrm{pH}$ meter. Plots of absorbance against $\lambda$ for the universal indicator in buffers with different $\mathrm{pH}$ levels are illustrated in Figure 4.

Neither the chemical composition of this indicator nor its dissociation constant was provided by the manufacturer. Therefore, spectrophotometric measurements were performed to determine its pKa, and two graphical and two analytical methods were applied. The results obtained using the different methods were compared, and the

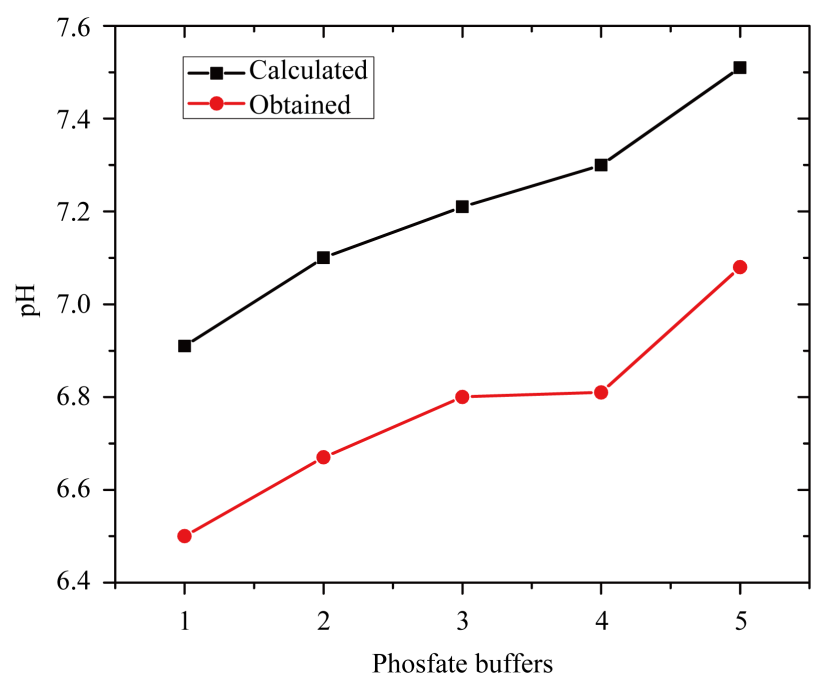

Figure 2. Comparison of the calculated and measured $\mathrm{pH}$ values for the phosphate buffers.

Table 5. Preparation of ammonium buffer at different concentrations and $\mathrm{pH}$.

\begin{tabular}{cccccc}
\hline & \multicolumn{2}{c}{ Volume of the STOCK aliquot $(\mathbf{m l})$} & \multicolumn{3}{c}{ Final preparation } \\
\hline Calculated $\mathbf{p H}$ & $\begin{array}{c}\text { Solution } \\
\mathbf{N H}_{\mathbf{3}}(\mathbf{m l})\end{array}$ & $\begin{array}{c}\text { Solution } \\
\mathbf{N H}_{\mathbf{4}} \mathbf{C l}(\mathbf{m l})\end{array}$ & $\begin{array}{c}\text { Final volume } \\
\text { buffer }(\mathbf{m l})\end{array}$ & $\begin{array}{c}\text { Concentration } \\
\text { buffer }(\mathbf{M})\end{array}$ & Obtained pH \\
\hline 8.44 & 30 & 5 & 50 & 0.306 & 9.0 \\
9.04 & 15 & 10 & 25 & 0.213 & 9.48 \\
9.22 & 15 & 15 & 100 & 0.253 & 9.81 \\
9.58 & 15 & 35 & 100 & 0.413 & 10.25 \\
9.99 & 5 & 30 & 50 & 0.284 & 10.85 \\
\hline
\end{tabular}




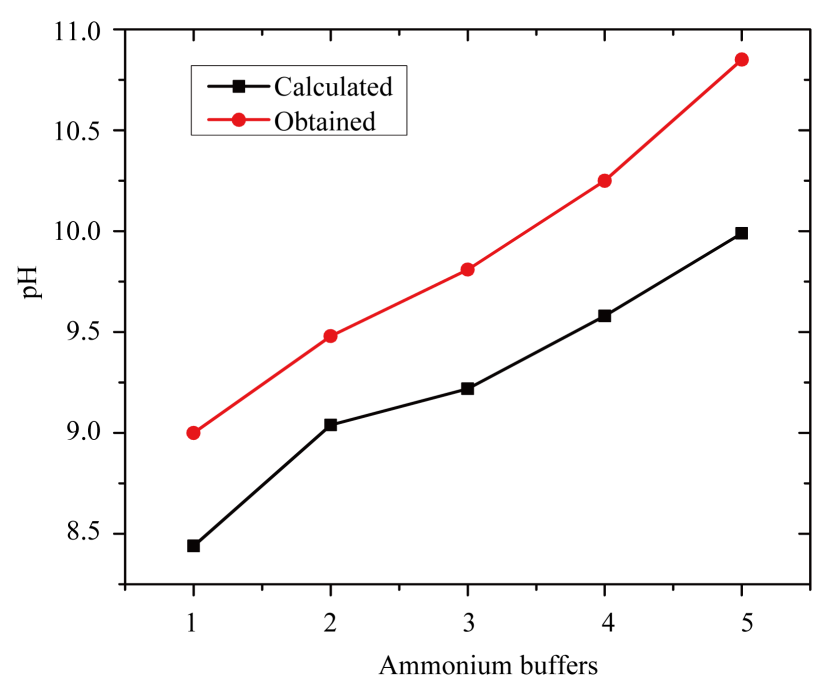

Figure 3. Comparison of the measured and calculated $\mathrm{pH}$ values for ammonium buffers.
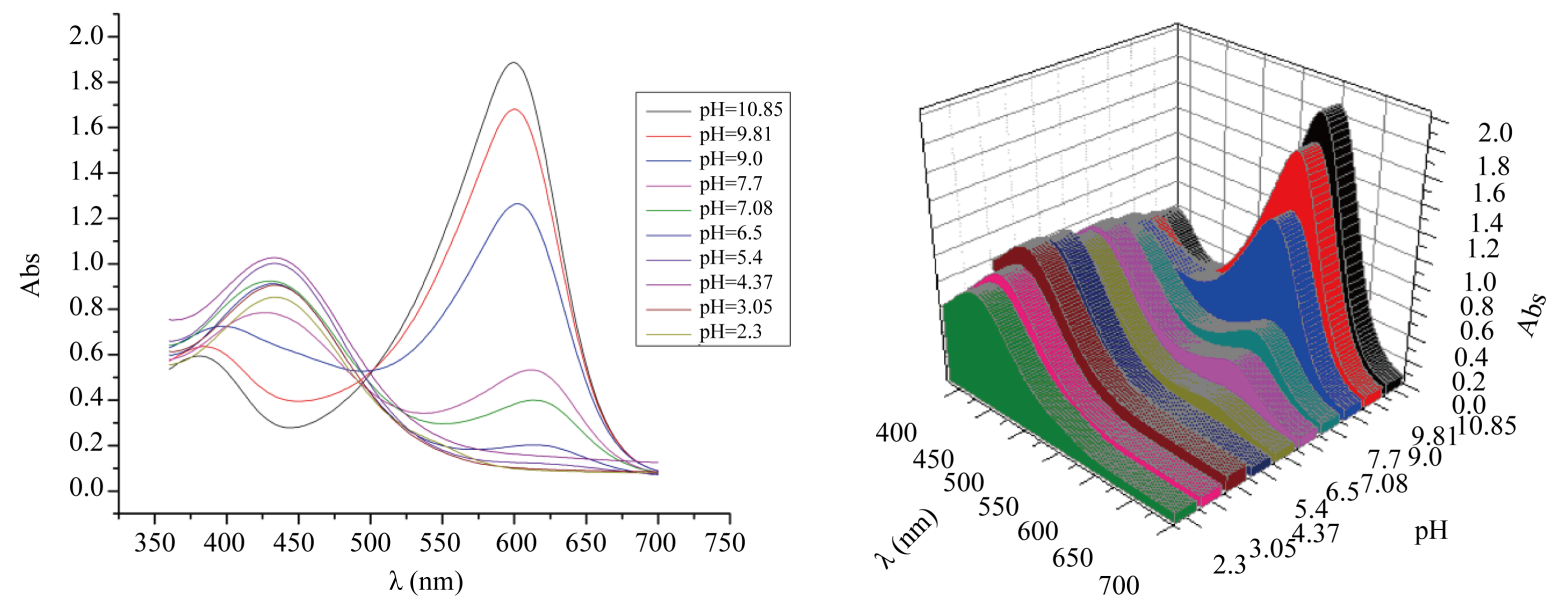

Figure 4. Absorbance spectra of the universal indicator pH 1 - 11 at different $\mathrm{pH}$ levels.

most suitable pKa value was determined. The first method was to take the spectra of the species with extreme pHlevels ( $\mathrm{pH}=2.3$ and $\mathrm{pH}=10.85$ in this case) and determine the wavelengths of maximum absorbance, as illustrated in Figure 5.

As illustrated in Figure 5, the absorbance spectrum of the solution of $\mathrm{pH}=2.3$ exhibited a peak at $434 \mathrm{~nm}$; the peak of the basic solution occurred at $600 \mathrm{~nm}$. The plot of the absorbance vs. pH at these wavelengths is presented in Figure 6.

The pKa was obtained by determining the $\mathrm{pH}$ of the point of intersection of the two linear curves as shown in Figure 6. To determine this point, the linear equations of the two points closest to the crossing at each curve were solved:

where

$$
0.5759 x-3.9759=-0.1069 x+1.5406
$$

$$
x=\frac{5.5165}{0.6828}=8.0792
$$

Thus,

$$
\mathrm{pKa}=8.0792
$$

The second method was to plot $\log \left[\left(\mathrm{A}_{\mathrm{HA}}-\mathrm{A}_{\mathrm{i}}\right) /\left(\mathrm{A}_{\mathrm{i}}-\mathrm{A}_{\mathrm{A}}\right)\right]$ vs. $\mathrm{pH}$ (Equation (9)), where $\mathrm{A}_{\mathrm{HA}}$ is the ab- 


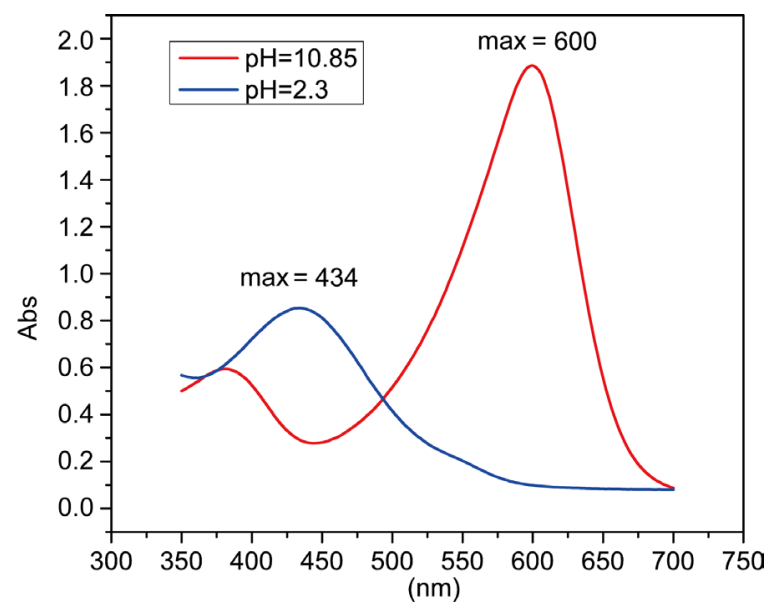

Figure 5. Absorbance spectra of universal indicator solutions at extreme $\mathrm{pH}$ levels.

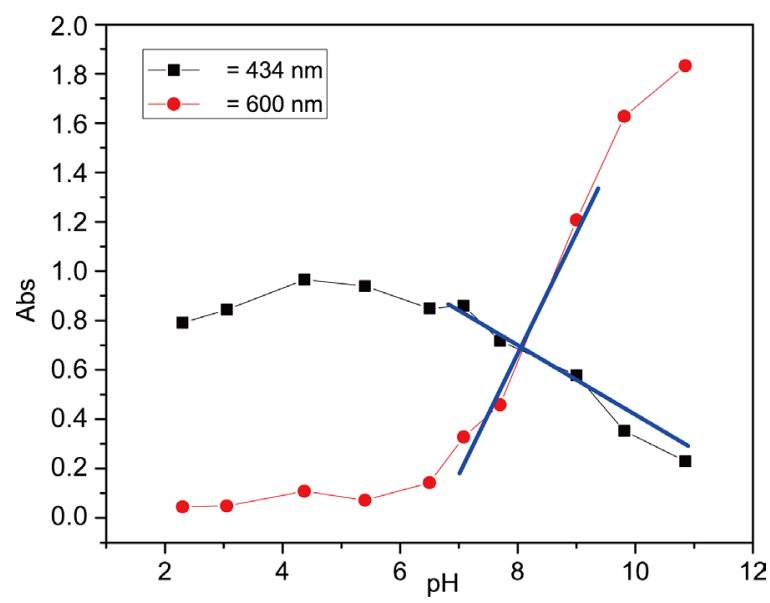

Figure 6. Plot of absorbance vs. pHat wavelengths of 434 and $600 \mathrm{~nm}$.

sorbance of the acid solution, $A_{i}$ is each of the intermediate absorbances and $A_{A}$ is the absorbance of the basic solution. For the best results, the wavelength where the difference between the absorbance curves of the acidic and basic solutions is greatest must be chosen, which, in this case, corresponds to $\lambda=600 \mathrm{~nm}$.

When linear regression of the data is performed, the resulting equation is

$$
\log \left[\frac{\left(A_{H A}-A_{i}\right)}{\left(A_{i}-A_{A^{-}}\right)}\right]=0.53119 p H-4.51552
$$

A graph of the data and the linear regression are shown in Figure 7.

The pKa is obtained from the intercept of the line with the $x$-axis according to the equation

$$
\log \left[\frac{\left(A_{H A}-A_{i}\right)}{\left(A_{i}-A_{A^{-}}\right)}\right]=\mathrm{pH}_{i}-p K a
$$

In addition, $\log \left[\frac{\left(\mathrm{A}_{\mathrm{HA}}-\mathrm{A}_{\mathrm{i}}\right)}{\left(\mathrm{A}_{\mathrm{i}}-\mathrm{A}_{\mathrm{A}^{-}}\right)}\right]=0$

We have 


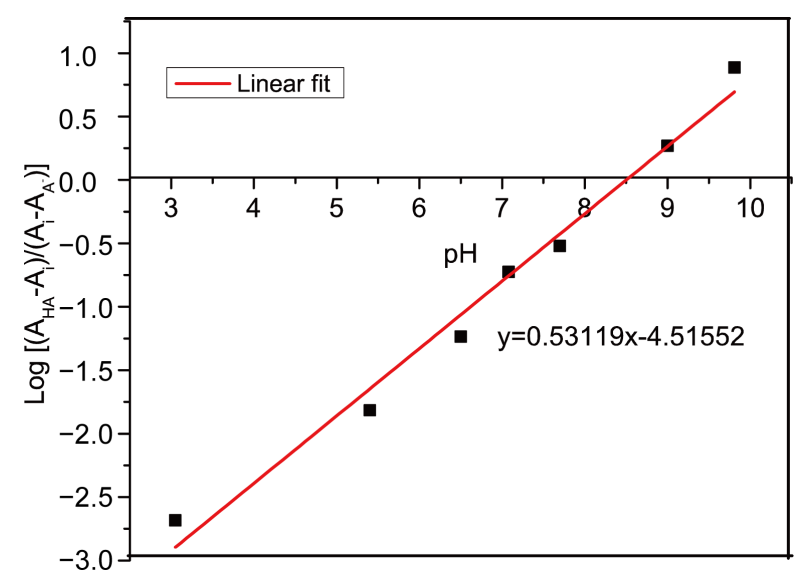

Figure 7. Linear regression of $\log \left[\left(\mathrm{A}_{\mathrm{HA}}-\mathrm{A}_{\mathrm{i}}\right) /\left(\mathrm{A}_{\mathrm{i}}-\mathrm{A}_{\mathrm{A}}\right)\right]$ vs. $\mathrm{pH}$.

$$
0=0.53119 \mathrm{pH}-4.51552
$$

resulting in $\mathrm{pH}=\frac{4.51552}{0.53119}=8.50076=\mathrm{pKa}$

The third method is to use Equation (8) solved for pKa:

$$
\mathrm{pKa}=\mathrm{pH}_{\mathrm{i}}-\log \left[\frac{\left(\mathrm{A}_{\mathrm{HA}}-\mathrm{A}_{\mathrm{i}}\right)}{\left(\mathrm{A}_{\mathrm{i}}-\mathrm{A}_{\mathrm{A}^{-}}\right)}\right]
$$

where $\mathrm{pH}_{\mathrm{i}}$ is the intermediate value between the acid and alkaline extreme values. The intermediate $\mathrm{pH}$ selected was $\mathrm{pH}=7.7$, which was chosen because of the substantial coincidence of its isosbestic point with those of the extreme-pH solutions, as illustrated in Figure 8.

Equation (16) was then applied to all wavelengths, resulting in the graph shown in Figure 9.

The average of all of the data gives $\mathrm{pKa}=8.26272$. The isosbestic point was determined by taking the wavelength value where the standard deviation of absorbance was minimal. The isosbestic point appeared at a wavelength of $494 \mathrm{~nm}$.

The fourth method, which is similar to the third, was based on the absorbance of three solutions with different $\mathrm{pH}$ values (i.e., a very acidic, a very basic and one intermediate-pH solution) at the same wavelength. The pKa was obtained by substituting these values into the following equation:

$$
\mathrm{pK}_{\mathrm{a}}=\mathrm{I}-\log \frac{\left(10^{\mathrm{b}}-10^{\mathrm{a}}\right) \mathrm{A}_{1}+\left(1-10^{\mathrm{b}}\right) \mathrm{A}_{2}+\left(10^{\mathrm{a}}-1\right) \mathrm{A}_{3}}{\left(10^{\mathrm{a}}-10^{\mathrm{b}}\right) \mathrm{A}_{1}+\left(10^{\mathrm{a}+\mathrm{b}}-10^{\mathrm{a}}\right) \mathrm{A}_{2}+\left(10^{\mathrm{b}}-10^{\mathrm{a}+\mathrm{b}}\right) \mathrm{A}_{3}}
$$

where I represents the lowest $\mathrm{pH}$ value (in this case, 2.3); a corresponds to the difference between the intermediate $\mathrm{pH}$ and the I value $(\mathrm{a}=7.7-2.3=5.4)$; $\mathrm{b}$ is the difference between the most alkaline $\mathrm{pH}$ and the most acidic $(b=10.85-2.3=8.55) ; A_{1}, A_{2}$ and $A_{3}$ are the absorbances at each $\mathrm{pH}$ value for a given wavelength. The calculated pKa data are plotted as a function of wavelength in Figure 10.

The average of all of the data gave $\mathrm{pKa}=8.26466$, which is very similar to that determined using the third method. Table 6 shows a summary of the results obtained using the four methods.

The average value obtained using the four methods correspond to a pKa of 8.277. The results obtained using these equations were similar, with a standard deviation of only 0.00137 ; thus, the average of these two values was taken as the most appropriate result for the $\mathrm{pKa}$ of the indicator in this report:

$$
\mathrm{pKa}=8.264 \pm 0.001
$$

Finally, an equation for the relationship between the absorbance and the $\mathrm{pH}$ at a wavelength of $600 \mathrm{~nm}$ was obtained. This wavelength was selected because it is the value where the absorbance is highest and produces the greatest rate of change in Equations (17) and (18). The absorbance as a function of $\mathrm{pH}$ was obtained via non- 


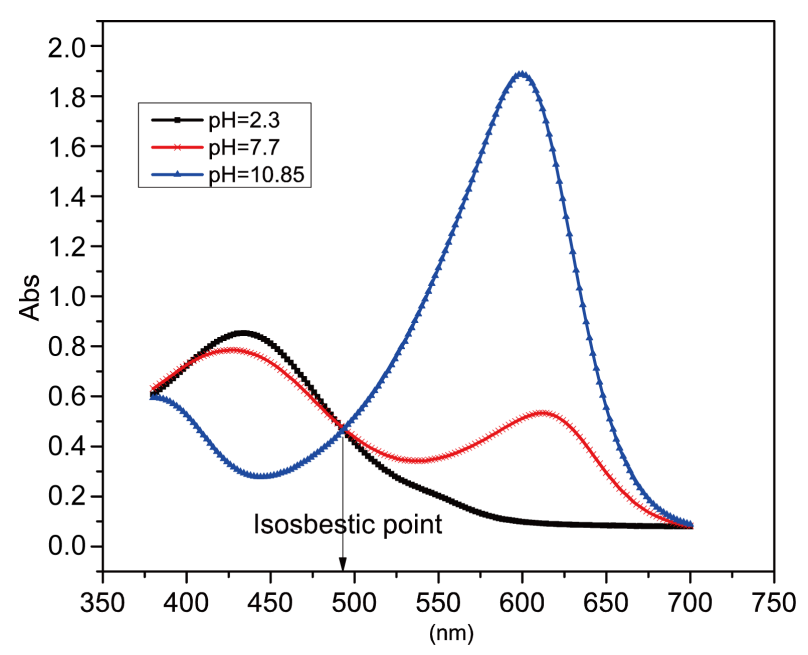

Figure 8. Absorbance curves for the acidic, basic, and intermediate $\mathrm{pH}$ solutions.

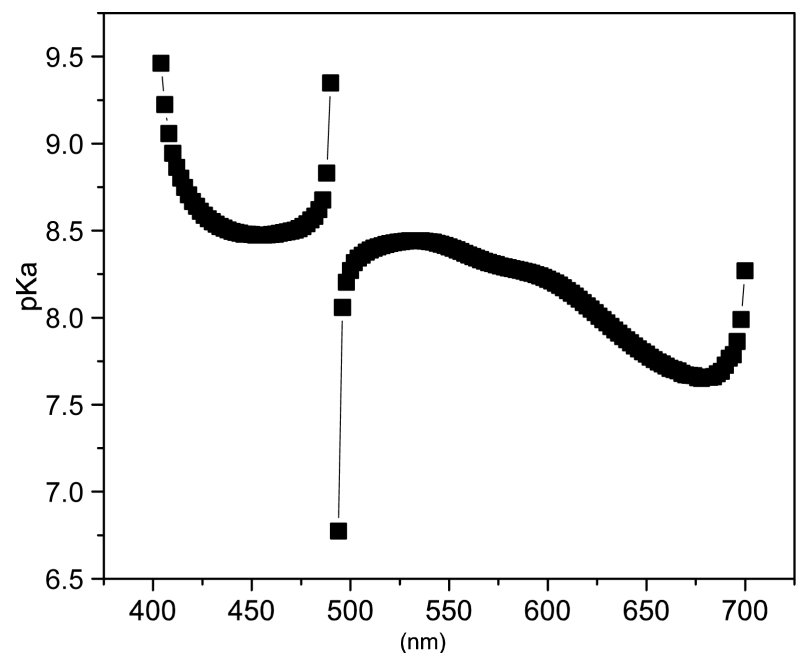

Figure 9. Curve of values obtained from Equation (17).

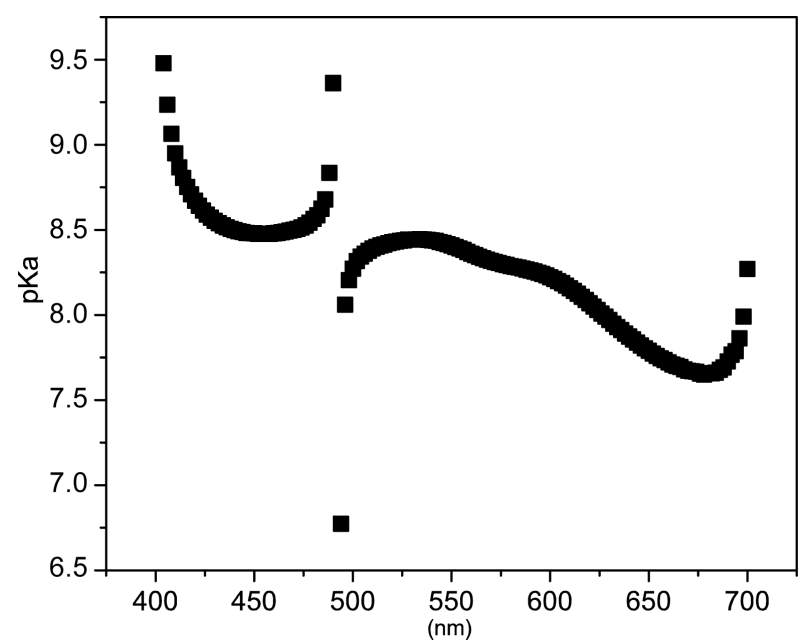

Figure 10. Graph of pKa vs. $\lambda$ for pKa values calculated using Equation (18). 
linear curve fitting in OriginProusing the Gaussian equation, which provided the best fit to the data. Figure 11 shows the data and the curve of best fit.

The data from the best-fit equation are shown in Table 7 .

Therefore, the equation can be written as

Table 6. Comparison of the pKa data obtained using the different methods.

\begin{tabular}{cc}
\hline Equation & pKa \\
\hline Graphicmethod 1 & 8.079 \\
Graphicmethod 2 & 8.501 \\
By Equation (17) & 8.263 \\
By Equation (18) & 8.265 \\
Average & 8.277 \\
Standard deviation & 0.173 \\
\hline
\end{tabular}

Table 7. Equation modeling of absorbance as a function of $\mathrm{pH}$.

\begin{tabular}{cccc}
\hline Model & \multicolumn{2}{c}{ Gauss Amp } & \\
\hline Equation & & $\mathrm{Y}=\mathrm{y}_{0}+\mathrm{A} \times \exp \left(-0.5 \times\left(\left(\mathrm{x}-\mathrm{x}_{\mathrm{c}}\right) / \mathrm{w}\right)^{2}\right)$ & \\
Reduced Chi-sqr & & 0.00106 & \\
Adj. R-square & & 0.99782 & Standard error \\
& & Value & 0.01665 \\
& $y_{0}$ & 0.06116 & 0.09151 \\
$\mathrm{~B}$ & $\mathrm{x}_{\mathrm{c}}$ & 10.67743 & 0.0765 \\
& $\mathrm{w}$ & 1.76403 & 0.03152 \\
& $\mathrm{~A}$ & 1.77771 & \\
\hline
\end{tabular}

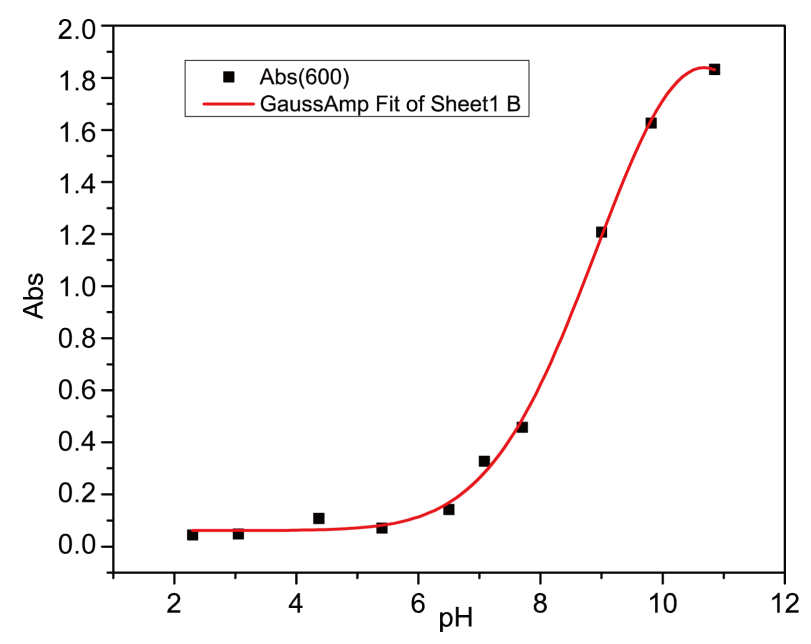

Figure 11. Equation for the absorbance vs. $\mathrm{pH}$ at $\lambda=600$ nm. 


$$
\operatorname{Abs}_{\lambda=600 \mathrm{~nm}}=6.116 \times 10^{-2}+1.778 \times \operatorname{Exp}\left[-0.5 \times\left(\frac{(\mathrm{pH}-10.68)}{1.764}\right)^{2}\right]
$$

\section{Conclusion}

The application of spectrophotometric titration allowed the acid dissociation constant of universal pH indicator 1 11 from Carlo Ebra to be determined. Four methods of analysis - two graphical and two mathematical methods - were used and produced results with good similarity, especially in the cases of the two mathematical methods. Some colorimetric $\mathrm{pH}$ indicators, such as bromothymol blue in acidic solutions, are unstable over long periods of time, whereas the studied universal indicator retains its color even months after being exposed to highly acidic solutions. This property and the significant color variation make the development of a technique for spectrophotometric measurement of $\mathrm{pH}$ interesting. An equation was obtained for the relationship between absorbance and $\mathrm{pH}$ with a very low dispersion, and the isosbestic point was determined.

\section{References}

[1] Zscherp, C., Schlesinger, R., Tittor, J., Oesterhelt, D. and Heberle, J. (1999) In Situ Determination of Transient pka Changes of Internal Aminoacids of Bacteriorhodopsin by Using Time-Resolved Attenuated Total Reflection FourierTransform Infrared Spectroscopy. Biophysics: Proceedings of the National Academy of Sciences, 96, 5498-5503.

[2] Baran, Y., Baran, S. and Kemal, N. (1997) Spectofotometric Determination of the pKa Values of Some Aminoacid Complexes of Pentacyanoferrate (II) and Pentacyanoruthenate (II). Journal of Chemistry, 21, 105-110.

[3] Meloun, M., Bordovská, S. and Vrana, A. (2007) The Thermodynamic Dissociation Constants of the Anticancer Drugs Camptothecine, 7-Ethyl-10-hydroxycamptothecine, 10-Hydroxycamptothecine and 7-Ethylcamptothecine by the LeastSquares Nonlinear Regression of Multiwavelength Spectrophotometric pH-Titration Data. Analytica Chimica Acta, 584, 419-432. http://dx.doi.org/10.1016/j.aca.2006.11.049

[4] Meloun, M., Bordovská, S. and Galla, L. (2007) The Thermodynamic Dissociation Constants of Four Non-Steroidalanti-Inflammatory Drugs by the Least-Squares Nonlinear Regression of Multiwavelength Spectrophotometric pH-Titration Data. Journal of Pharmaceutical and Biomedical Analysis, 45, 552-564. http://dx.doi.org/10.1016/i.jpba.2007.07.029

[5] Mitchell, R.C., Salter, C.J. and Tam, K.Y. (1999) Multiwavelength Spectrophotometric Determination of Acid Dissociation Constants Part III: Resolution of Multi-Protic Ionization Systems. Journal of Pharmaceutical and Biomedical Analysis, 20, 289-295. http://dx.doi.org/10.1016/S0731-7085(99)00041-2

[6] Tam, K.Y., Hadley, M. and Patterson. W. (1999) Multiwavelength Spectrophotometric Determination of Acid Dissociation Constants Part IV: Water-Insoluble Pyridine Derivatives. Talanta, 49, 539-546. http://dx.doi.org/10.1016/S0039-9140(99)00010-7

[7] Amador-Hernández, J., Rojas-Hernández, A. Madaí, E., De La Garza-Rodríguez, M., Velázquez-Manzanares, M. and Medina-Vallejo, L.F. (2014) New Chemometric Strategies in the Spectrophotometric Determination of pKa. European Journal of Chemistry, 5, 1-5. http://dx.doi.org/10.5155/eurjchem.5.1.1-5.901

[8] Ivanov, V.M., Adamova, E.M. and Figurovskaya, V.N. (2010) Acid-Base, Spectrophotometric, and Colorimetric Properties of 1, 2-Dihydroxyantraquinonone3-sulfoacid (Alizarin Red S). Journal of Analytical Chemistry, 65, 473-481. http://dx.doi.org/10.1134/S1061934810050072

[9] Kong, X., Zhou, T., Liu, Z. and Hider, R.C. (2007) pH Indicator Titration: A Novel Fast pKa Determination Method. Journal of Pharmaceutical Sciences, 96, 2777-2783. http://dx.doi.org/10.1002/jps.20959

[10] Meloun, M., Bordovská, S., Syrový, T. and Vrána, A. (2006) Tutorial on a Chemical Model Building by Least-Squares Non-Linear Regression of multiwavelength Spectrophotometric pH-Titration Data. Analytica Chimica Acta, 580, 107121. http://dx.doi.org/10.1016/j.aca.2006.07.043

[11] Meloun, M., Bordovská, S. and Syrovy, T. (2007) A Novel Computational Strategy for the pKa Estimation of Drugs by Non-Linear Regression of Multiwavelength Spectrophotometric pH-Titration Data Exhibiting Small Spectral Changes. Journal of Physical Organic Chemistry, 20, 690-701. http://dx.doi.org/10.1002/poc.1235

[12] Meloun, M., Ferencíková, Z. and Vrána, A. (2011) Determination of the Thermodynamic Dissociation Constant of Capecitabine Using Spectrophotometric and Potentiometric Titration Data. Journal of Chemical Thermodynamics, 43, 930-937. http://dx.doi.org/10.1016/j.jct.2011.01.012

[13] Panigrahi, S., Suna, P. and Misra, P.K. (2012) Effect of Organized Assemblies, Part VIII: Spectrophotometetric Study on the Effect of Micellar Media on the pK of Some Substituted N-Benzylideneanilines. Colloids and Surfaces A: Phy- 
sicochemical and Engineering Aspects, 415, 349-357. http://dx.doi.org/10.1016/j.colsurfa.2012.08.051

[14] Zapata, L., Kalembkiewicz, J. and Sitarz-Palczak, E. (2009) Studies on Equilibrium of Anthranilic Acid in Aqueous Solutions and in Two-Phase Systems: Aromatic Solvent-Water. Biophysical Chemistry, 140, 91-98. http://dx.doi.org/10.1016/j.bpc.2008.11.012

[15] Smith, S.A. and Pretorius, W.A. (1994) Spectrophotometric Determination of pKa Values for Fluorescein Using Activity Coefficient Corrections. Water SA, 28, 395-402.

[16] Skoog, D. and Leary, J. (1994) Análisis Instrumental. McGraw-Hill, Madrid.

[17] Harris, D.C. (1999) Quantitative Chemical Analysis. W.H. Freeman, New York.

[18] Vogel, A. (1969) Química Analítica Cuantitativa: Teoría y Práctica. Editorial Kapelusz, Buenos Aires. 
Scientific Research Publishing (SCIRP) is one of the largest Open Access journal publishers. It is currently publishing more than 200 open access, online, peer-reviewed journals covering a wide range of academic disciplines. SCIRP serves the worldwide academic communities and contributes to the progress and application of science with its publication.

Other selected journals from SCIRP are listed as below. Submit your manuscript to us via either submit@scirp.org or Online Submission Portal.
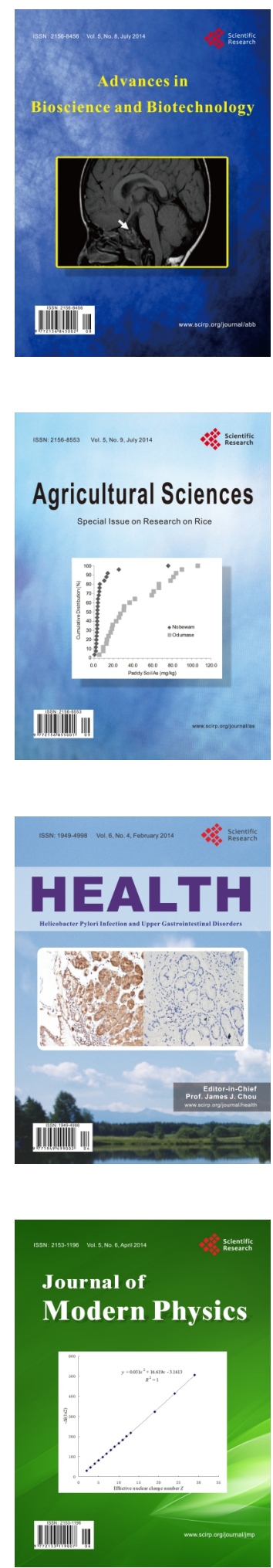
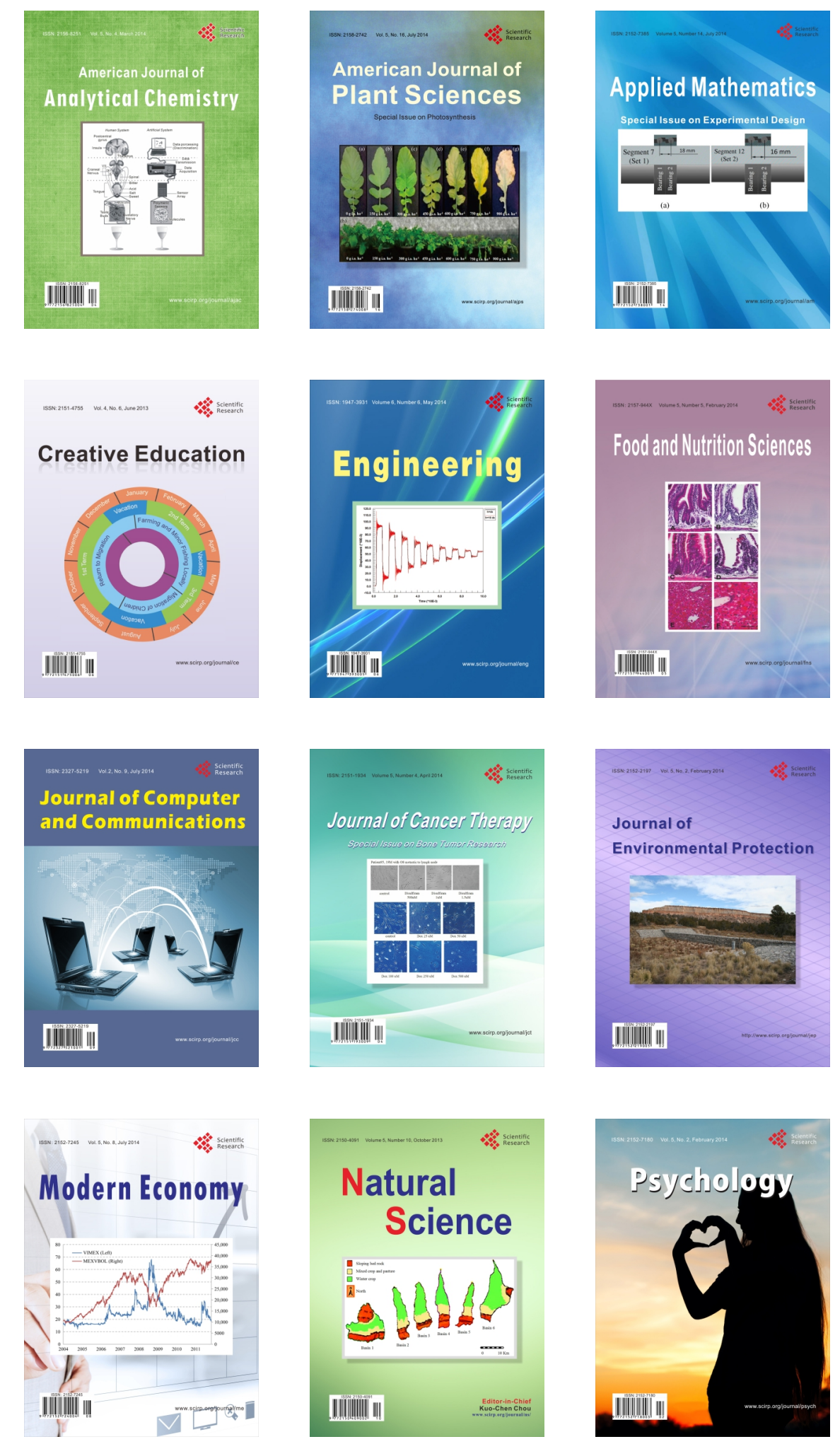